\title{
Effect of Nitrogen on Seed Yield, Protein Content and Nutrient Uptake of Soybean (Glycine max L.)
}

\author{
R. M. MORSHED ${ }^{1 *}$, M. M. RAHMAN ${ }^{1}$ \& M. A. RAHMAN ${ }^{2}$ \\ ${ }^{1}$ Department of Botany, Jahangirnagar University, Savar, Dhaka-1342, Bangladesh \\ ${ }^{2}$ Soil Resource Development Institute, Regional Laboratory, Mymensingh-2202, Bangladesh
}

\begin{abstract}
A pot experiment was conducted at the experimental space of Botany Department, Jahangirnagar University, Savar, Dhaka during rabi season 2004-2005 to determine the effect of nitrogen $(N)$ on yield, protein content and nutrient uptake of soybean using G-2 (Bangladesh soybean-4) as test crop. Rates of $N$ used were $O\left(N_{1}\right), 10.58\left(N_{2}\right), 15.87\left(N_{3}\right), 21.16\left(N_{4}\right), 26.45\left(N_{5}\right)$ and $31.74\left(N_{6}\right) \mathrm{kg} \mathrm{ha}^{-1}$ equivalent to $0,50,75,100,125$ and $150 \%$ of recommended $N$ doses. Seeds were inoculated with Bradyrhizobium inoculum before sowing. Nitrogen application progressively and significantly increased the yield of soybean upto the $N$ rate of $26.45 \mathrm{~kg} \mathrm{ha}^{-1}$ where the highest seed yield of $6.85 \mathrm{~g}$ plant ${ }^{-1}$ was obtained. Nutrient uptake and protein content in seeds also increased with increasing levels of $N$ ( up to the same rate of $26.45 \mathrm{~kg} \mathrm{~N} \mathrm{ha}^{-1}$ ). It is concluded that application of 25\% higher $\mathrm{N}$ over BARC recommendation could give maximum seed yield, protein content and nutrient uptake by soybean seed.
\end{abstract}

Key words: Soybean, nitrogen, yield, nutrient, protein.

\section{INTRODUCTION}

Soybean is called a miracle golden bean because of its nutritive value, especially as a substitute or complement of protein. Soybean is an excellent source of protein and therefore, can supplement protein in human diet. The approximate composition of soybean is $40-45 \%$ protein, $18-20 \%$ edible oil, 24-26\% carbohydrate and a good amount of vitamins (Kaul and Das, 1986). It thus can play an important role in supplementing oil-protein deficiency in Bangladesh. Soybean has been cultivated in Bangladesh as a minor crop and little attention is given on the improvement of its yield potential. Moreover, the yield of soybean is low in Bangladesh as compared to other countries of the world (Nasreen and Bhuiyan, 1997). Soybean has one of the highest $\mathrm{N}$ requirements among the most agronomic crops. It is grown in Bangladesh with no fertilizer or with biofertilizers. As a result, the average yield does not appear to be satisfactory.

Nitrogen is an integral component of many compounds, including chlorophyll and enzymes, essential for plant growth processes. It is an essential component of amino acids and related proteins. Nitrogen is essential for carbohydrate use within plants and stimulates root growth and development as well as the uptake of other nutrients. This element encourages above ground vegetative growth and gives a deep green color to the leaves (Brady, 1990). It is recognized that nitrogen is one of the key elements of soil fertility. Most of the developed countries are harvesting

* Corresponding author: 6/5, Humayun Road (3 ${ }^{\text {rd }}$ Floor), Block-B, Mohammadpur, Dhaka-1207. Mobile: 01552363392.

(C) 2008 School of Agriculture and Rural Development, Bangladesh Open University, All rights reserved. 
high yields and maintaining the soil nitrogen level by the application of chemical nitrogenous fertilizer. Soybean, being a leguminous crop, is capable to fix atmospheric nitrogen through symbiosis. However, several studies have shown that the symbiotic $\mathrm{N}$-fixation is not able to meet high $\mathrm{N}$-requirement of this crop particularly under the $\mathrm{N}$-deficient conditions. A number of workers (Duraisami and Mani, 2001; Kumawat et al., 2000; Bachhav and Sabale, 1996; Sharma and Misra, 1997) reported the positive role of nitrogen in increasing yield, protein content and nutrient uptake of soybean.

Unfortunately, there is lack of sufficient work on the yield, protein content and nutrient uptake of soybean due to application of $\mathrm{N}$. The present study was, therefore, undertaken to evaluate the effect of nitrogen on yield, protein content and nutrient uptake of soybean.

\section{MATERIALS AND METHODS}

A pot experiment was conducted at the experimental space of Botany Department, Jahangirnagar University, Savar, Dhaka, during rabi season of 2004-2005 with a view to know the effect of $\mathrm{N}$ on yield, protein content and nutrient uptake of soybean. Soil texture of the experimental soil was silty clay loam. The chemical properties of the experimental soil were total nitrogen (\%): 0.04 , available phosphorus (ppm): 16.36 , exchangeable potassium (meq/100 g soil): 0.32 , available sulphur (ppm): 27.82, soil $\mathrm{pH}: 5.3$. The experiment was laid out in a completely randomized design (CRD) with six levels of $\mathrm{N}$. Each treatment was replicated thrice. Levels of $\mathrm{N}$ used were: $0\left(\mathrm{~N}_{1}\right), 10.58\left(\mathrm{~N}_{2}\right), 15.87$ $\left(\mathrm{N}_{3}\right), 21.16\left(\mathrm{~N}_{4}\right), 26.45\left(\mathrm{~N}_{5}\right)$ and $31.74\left(\mathrm{~N}_{6}\right) \mathrm{kg} \mathrm{ha}^{-1}$ equivalents to 0, 50, 75, 100, 125 and 150\%, respectively, of the recommended $\mathrm{N}$ rate. Nitrogen was applied as urea. In addition to $\mathrm{N}$, other nutrients such as $\mathrm{P}, \mathrm{K}$ and S were applied @ 9.00, 7.50 and $1.80 \mathrm{~kg} \mathrm{ha}^{-1}$, respectively, as TSP, MP and Gypsum (BARC, 1997).

Each pot (20 cm diameter) was filled with $5.66 \mathrm{~kg}$ of previously grounded and dried soil. Pots were laid out according to the experimental design and placed one meter apart from each other. Fertilizers were applied in each pot according to treatments as basal dose. Soybean variety G-2 (Bangladesh Soybean-4) was used as the test crop in the experiment. Required amount of soybean seeds were inoculated with peat based inoculant (obtained from BARI) of Bradyrhizobium strain (BARI RGm-902) immediately before sowing. Three to four seeds per pot were sown on December 16, 2004. Necessary shading by newspaper was provided to preserve soil moisture until germination. Initially 3 plants were allowed to grow, but two weaker plants were uprooted at 10 days after germination keeping the healthiest one to grow. Weeding and other intercultural operations were done whenever necessary to keep the plants healthy. As needed, insecticide (Dersban $20 \mathrm{EC}$ ) was sprayed to control hairy caterpillar in all the pots. The plant was collected from each pot at harvesting stage after 123 days from the date of sowing (DAS) for estimation of seed weight. Seeds were analyzed in the SRDI laboratory for estimation of nutrient concentration and protein content. Data on different plant parameters was statistically analyzed and adjuged by Duncan's Multiple Range Test (DMRT) as outlined by Gomez and Gomez (1984).

\section{RESULTS AND DISCUSSION}

\section{a. Seed yield}

The effect of nitrogen on seed weight per plant of soybean was significant (Table 1). The highest seed weight $\left(6.85 \mathrm{~g} \mathrm{plant}^{-1}\right)$ was produced by $26.45 \mathrm{~kg} \mathrm{~N}$ ha $^{-1}$ in $\mathrm{N}_{5}$ treatment, which was $93.50 \%$ higher than that of control treatment. The seed weight was increased with increasing rates of $\mathrm{N}$ application up to $26.45 \mathrm{~kg} \mathrm{ha}^{-1}$ and there after it reduced. Reddy et al. (1990) reported that application of $60 \mathrm{~kg} \mathrm{~N} \mathrm{ha}^{-1}$ resulted in highest seed yield of soybean.

\section{b. Protein and nutrient content in seeds}

The effect of $\mathrm{N}$ on protein content in seeds of soybean was significant (Table 1). Protein content in seeds was progressively increased with increasing levels of $\mathrm{N}$ up to $26.45 \mathrm{~kg} \mathrm{~N}^{-1}$ in $\mathrm{N}_{5}$ treatment. The maximum protein content (44.75\%) in seeds produced by $\mathrm{N}_{5}$ treatment which was $16.23 \%$ higher than that in the control treatment but statistically similar to $\mathrm{N}_{4}$ treatment. Increase in protein 
content of soybean with increasing level of $\mathrm{N}$ was also reported by many workers (Eman, 2002; Kumawat et al., 2000; Bachhav and Sabale, 1996). The trend of variation in protein content was similar to that of $\mathrm{N}$ content because protein content was computed by multiplying the $\mathrm{N}$ content in seeds with 6.25 . The significantly highest nitrogen content in seeds $(7.16 \%)$ was obtained in the treatment of $\mathrm{N}_{5}$ which was statistically similar to $\mathrm{N}_{4}$ and superior to the rest of the treatment and the lowest nitrogen content in seeds (6.16\%) was obtained in control $\left(\mathrm{N}_{1}\right)$ treatment (Table 1$)$.

Table 1. Effect of nitrogen on seed yield, protein and nutrient content of soybean

\begin{tabular}{lcccccc}
\hline \multirow{2}{*}{ Treatment } & Seed yield & \% protein content & \multicolumn{4}{c}{ Nutrient content in seeds (\%) } \\
\cline { 5 - 7 } & $(\mathrm{g} \mathrm{plant})$ & in seeds & $\mathrm{N}$ & $\mathrm{P}$ & $\mathrm{K}$ & $\mathrm{S}$ \\
\hline $\mathrm{N}_{1}\left(0 \mathrm{~kg} \mathrm{ha}^{-1}\right)$ & $3.54 \mathrm{~d}$ & $38.50 \mathrm{~b}$ & $6.16 \mathrm{~b}$ & $0.57 \mathrm{ab}$ & $0.61 \mathrm{a}$ & 0.40 \\
$\mathrm{~N}_{2}\left(10.58 \mathrm{~kg} \mathrm{ha}^{-1}\right)$ & $3.94 \mathrm{~cd}$ & $38.75 \mathrm{~b}$ & $6.20 \mathrm{~b}$ & $0.58 \mathrm{a}$ & $0.55 \mathrm{ab}$ & 0.44 \\
$\mathrm{~N}_{3}\left(15.87 \mathrm{~kg} \mathrm{ha}^{-1}\right)$ & $4.59 \mathrm{c}$ & $39.19 \mathrm{~b}$ & $6.27 \mathrm{~b}$ & $0.51 \mathrm{c}$ & $0.51 \mathrm{~b}$ & 0.40 \\
$\mathrm{~N}_{4}\left(21.16 \mathrm{~kg} \mathrm{ha}^{-1}\right)$ & $5.98 \mathrm{ab}$ & $43.75 \mathrm{a}$ & $7.00 \mathrm{a}$ & $0.55 \mathrm{~b}$ & $0.47 \mathrm{~b}$ & 0.44 \\
$\mathrm{~N}_{5}\left(26.45 \mathrm{~kg} \mathrm{ha}^{-1}\right)$ & $6.85 \mathrm{a}$ & $44.75 \mathrm{a}$ & $7.16 \mathrm{a}$ & $0.52 \mathrm{c}$ & $0.47 \mathrm{~b}$ & 0.48 \\
$\mathrm{~N}_{6}\left(31.74 \mathrm{~kg} \mathrm{ha}^{-1}\right)$ & $5.58 \mathrm{~b}$ & $40.69 \mathrm{~b}$ & $6.51 \mathrm{~b}$ & $0.56 \mathrm{ab}$ & $0.50 \mathrm{~b}$ & 0.46 \\
\hline $\mathrm{CV}(\%)$ & 10.61 & 3.01 & 3.01 & 3.65 & 9.19 & 10.49 \\
\hline
\end{tabular}

Means in a column followed by same letter(s) are not significantly different at $5 \%$ level as per DMRT

Data on phosphorus content in seeds was affected by different nitrogen treatment (Table 1 ). The highest phosphorus content in seeds $(0.58 \%)$ was obtained in $\mathrm{N}_{2}$ and it was statistically similar to $N_{1}$ and $N_{6}$ treatment. The lowest phosphorus content in seeds $(0.51 \%)$ was produced by $N_{3}$ treatment. In this experiment, there was no positive effect between $\mathrm{N}$ application and $\mathrm{P}$ content in seeds. But Tufenkci et al. (2006) reported that increasing rate of $\mathrm{N}$ fertilizer applications significantly increased the contents of phosphorus in shoot of soybean.

A significant variation in potassium content in seeds of soybean was observed due to variation of nitrogen levels (Table 1$)$. The maximum potassium content in seeds $(0.61 \%)$ was recorded in $\mathrm{N}_{1}$ treatment and the lowest potassium content in seeds $(0.47 \%)$ was recorded in $N_{4}$ and $N_{5}$ treatments. All the treatments except control $\left(\mathrm{N}_{1}\right)$ were statistically similar.

Sulphur content in seeds was not significantly influenced by different levels of nitrogen (Table 1). The highest sulphur content (0.48\%) in seeds was recorded by $26.45 \mathrm{~kg} \mathrm{~N}^{-1}$ in $\mathrm{N}_{5}$ treatment and the lowest $(0.40 \%)$ was obtained by $\mathrm{N}_{1}$ and $\mathrm{N}_{3}$ treatment.

\section{c. Nutrient uptake by seeds}

Nitrogen uptake by seeds increased with increasing level of $N$ up to certain level (Table 2). The highest $\mathrm{N}$ uptake (490.78 mg plant ${ }^{-1}$ ) was noted by $26.45 \mathrm{~kg} \mathrm{~N} \mathrm{ha}^{-1}$ in $\mathrm{N}_{5}$ treatment which was statistically superior to the rest of the treatments. With the increase of nitrogen levels increased the nitrogen uptake by seeds of the crop up to $26.45 \mathrm{~kg} \mathrm{~N} \mathrm{ha}^{-1}$. The lowest $\mathrm{N}$ uptake (218.42 $\mathrm{mg} \mathrm{plant}^{-1}$ ) was found by control treatment. Duraisami and Mani (2001) found that the uptake of $\mathrm{N}$ by soybean was favourably affected by the residual effect of $\mathrm{N}$ levels. Kumawat et al. (2000) reported that the $\mathrm{N}$ uptake by seeds of soybean significantly increased with the increase in $\mathrm{N}$ up to $60 \mathrm{~kg} \mathrm{ha}^{-1}$.

The influence of different levels of nitrogen on $\mathrm{P}$ uptake by seeds of soybean was significant (Table 2). The highest $P$ uptake ( $35.50 \mathrm{mg} \mathrm{plant}^{-1}$ ) by seeds was found by $26.45 \mathrm{~kg} \mathrm{~N}^{-1}$ in $\mathrm{N}_{5}$ treatment and the lowest $\left(20.22 \mathrm{mg} \mathrm{plant}^{-1}\right)$ by control treatment $\left(\mathrm{N}_{1}\right)$. It was observed that the phosphorus uptake by seeds of soybean per plant increased significantly with the increase of nitrogen levels up to $26.45 \mathrm{~kg} \mathrm{~N} \mathrm{ha}^{-1}$ and then decreased. Duraisami and Mani (2001) found that the uptake of $\mathrm{P}$ by soybean was favourably affected by the residual effect of $\mathrm{N}$ levels. Kumawat $e t$ al. (2000) reported that the $P$ uptake by seeds of soybean significantly increased with the increase in $\mathrm{N}$ up to $60 \mathrm{~kg} \mathrm{ha}^{-1}$. Sharma and Misra (1997) also observed that the highest uptake of $\mathrm{P}$ by soybean produced with the application of $20 \mathrm{~kg} \mathrm{~N} \mathrm{ha}^{-1}$ along with FYM. 
Table 2. Effect of nitrogen on nutrient uptake by seeds of soybean

\begin{tabular}{lcccc}
\hline \multirow{2}{*}{ Treatment } & \multicolumn{4}{c}{ Nutrient uptake by seeds (mg/plant) } \\
\cline { 2 - 5 } & $\mathrm{N}$ & $\mathrm{P}$ & $\mathrm{K}$ & $\mathrm{S}$ \\
\hline $\mathrm{N}_{1}\left(0 \mathrm{~kg} \mathrm{ha}^{-1}\right)$ & $218.42 \mathrm{~d}$ & $20.22 \mathrm{~b}$ & $21.47 \mathrm{c}$ & $14.38 \mathrm{c}$ \\
$\mathrm{N}_{2}\left(10.58 \mathrm{~kg} \mathrm{ha}^{-1}\right)$ & $244.43 \mathrm{~cd}$ & $22.86 \mathrm{~b}$ & $21.68 \mathrm{c}$ & $17.35 \mathrm{c}$ \\
$\mathrm{N}_{3}\left(15.87 \mathrm{~kg} \mathrm{ha}^{-1}\right)$ & $287.71 \mathrm{c}$ & $23.40 \mathrm{~b}$ & $23.40 \mathrm{bc}$ & $18.36 \mathrm{c}$ \\
$\mathrm{N}_{4}\left(21.16 \mathrm{~kg} \mathrm{ha}^{-1}\right)$ & $417.69 \mathrm{~b}$ & $32.80 \mathrm{a}$ & $28.06 \mathrm{ab}$ & $26.27 \mathrm{~b}$ \\
$\mathrm{~N}_{5}\left(26.45 \mathrm{~kg} \mathrm{ha}^{-1}\right)$ & $490.78 \mathrm{a}$ & $35.50 \mathrm{a}$ & $32.13 \mathrm{a}$ & $32.82 \mathrm{a}$ \\
$\mathrm{N}_{6}\left(31.74 \mathrm{~kg} \mathrm{ha}^{-1}\right)$ & $362.96 \mathrm{~b}$ & $31.22 \mathrm{a}$ & $28.07 \mathrm{ab}$ & $25.65 \mathrm{~b}$ \\
$\mathrm{CV}(\%)$ & 10.84 & 8.60 & 10.19 & 13.40 \\
\hline
\end{tabular}

Means in a column followed by same letter(s) are not significantly different at $5 \%$ level as per DMRT

Potassium uptake by seeds was significantly influenced by different levels of nitrogen (Table 2). Nitrogen influenced significantly higher uptake of $\mathrm{K}$ by seeds of the crop. The highest $\mathrm{K}$ uptake (32.13 $\mathrm{mg} \mathrm{plant}^{-1}$ ) was produced by $26.45 \mathrm{~kg} \mathrm{~N} \mathrm{ha}^{-1}$ in $\mathrm{N}_{5}$ treatment. The potassium uptake by seeds of the crop per plant increased significantly with the increase of nitrogen levels up to 26.45 $\mathrm{kg} \mathrm{N} \mathrm{ha}^{-1}$ and then it was declined. The lowest $\mathrm{K}$ uptake $\left(21.47 \mathrm{mg} \mathrm{plant}^{-1}\right)$ was recorded by control treatment $\left(\mathrm{N}_{1}\right)$. Duraisami and Mani (2001) found that the uptake of $\mathrm{K}$ by soybean was favorably affected by the residual effect of $\mathrm{N}$ levels. Sharma and Misra (1997) observed that the highest uptake of $\mathrm{K}$ by soybean produced with the application of $20 \mathrm{~kg} \mathrm{~N} \mathrm{ha}^{-1}$ along with FYM.

Sulphur uptake by seeds was influenced by different levels of nitrogen (Table 2). The effect of nitrogen on $\mathrm{S}$ uptake by seeds of soybean was found positive and significant. Maximum $\mathrm{S}$ uptake of $32.82 \mathrm{mg} \mathrm{plant}^{-1}$ was found by $26.45 \mathrm{~kg} \mathrm{~N} \mathrm{ha}^{-1}$ in $\mathrm{N}_{5}$ treatment. The sulphur uptake per plant was found to be increased gradually up to $125 \%$ BARC recommendation and then declined. The lowest $\mathrm{S}$ uptake (14.38 $\mathrm{mg} \mathrm{plant}^{-1}$ ) was noted in control treatment. This result was in agreement with that of Sharma and Misra (1997) where they observed that the highest uptake of $S$ by soybean produced with the application of $20 \mathrm{~kg} \mathrm{~N} \mathrm{ha}^{-1}$ along with FYM.

\section{CONCLUSION}

From this study it may be concluded that nitrogen has positive effect on yield, protein content and nutrient uptake of soybean. Application of nitrogen up to $26.45 \mathrm{~kg} \mathrm{ha}^{-1}$ ( $25 \%$ higher than BARC recommendation) gave the maximum yield, protein content and nutrient uptake of soybean. So, application of nitrogen could be increased by $25 \%$ higher over BARC recommendation for higher yield, protein content and nutrient uptake of soybean.

\section{LITERATURE CITED}

Bachhav, P. R. and Sabale, R. N. 1996. Effects of different sources of nitrogen on growth parameters, yield and quality of soybean. J Maharashtra Agric Univ 21(2), 244-247.

BARC. 1997. "Fertilizer Recommendation Guide-1997". Farmgate, Dhaka.

Brady, N. C. 1990. "The Nature and Properties of Soils" (Tenth Edn.). Macmillan Publishing Company, New York. 315 pp.

Duraisami, V. P. and Mani, A. K. 2001. Residual effect of inorganic nitrogen, composted coirpith and biofertilizer on yield and uptake of soybean in an Inceptisol. Madras Agric J 88(4/6), 277280.

Eman, S. S. 2002. Response of growth, yield and attributes of soybean plants [(Glycin max (L.) Merr.)] to late soil nitrogen fertilization. Arab Univ J Agric Sci 10(1), 165-172.

Gomez, A. K. and Gomez, A. A. 1984. "Statistical Procedures for Agricultural Research" (Second Edn.). John Wiley and Sons, New York. pp. 139-240. 
Kaul, A. K. and Das, M. L. 1986. "Oilseeds in Bangladesh". Bangladesh Canada Agriculture Sector Team, Ministry of Agriculture, Government of the People's Republic of Bangladesh, Dhaka. pp. 324.

Kumawat, S. M., Dhakar, L. L. and Maliwal, P. L. 2000. Effect of irrigation regimes and nitrogen on yield, oil content and nutrient uptake of soybean (Glycine max). Indian J Agron 45(2), 361-366.

Nasreen, S. and Bhuiyan, M. A. H. 1997. Response of soybean (Glycine max L.) to phosphorus and sulphur fertilization. Bang J Agril Sci 24(1), 111-116.

Reddy, T. R., Rao, M. and Rao, K. R. 1990. Response of soybean (Glycine max L) to nitrogen and phosphorus. Indian J Agron 35, 310-311.

Sharma, R. A. and Misra, O. R. 1997. Crop residues, FYM and fertilizer use in relation to growth, yield and nutrient uptake by soybean. Crop Res Hisar 13(1), 51-57.

Tufenkci, S., Sonmez, F. and Sensoy, R. I. G. 2006. Effects of Arbuscular Mycorrhiza fungus inoculation and phosphorus and Nitrogen fertilizations on some plant growth parameters and nutrient content of soybean. Pak J Biol Sci 9(6), 1121-1127. 